u.s. DePARTMEnt of | Energy Efficiency \&

בNGeY Renewable Energy

Challenges and Successes on the Path toward a Solar-Powered Community
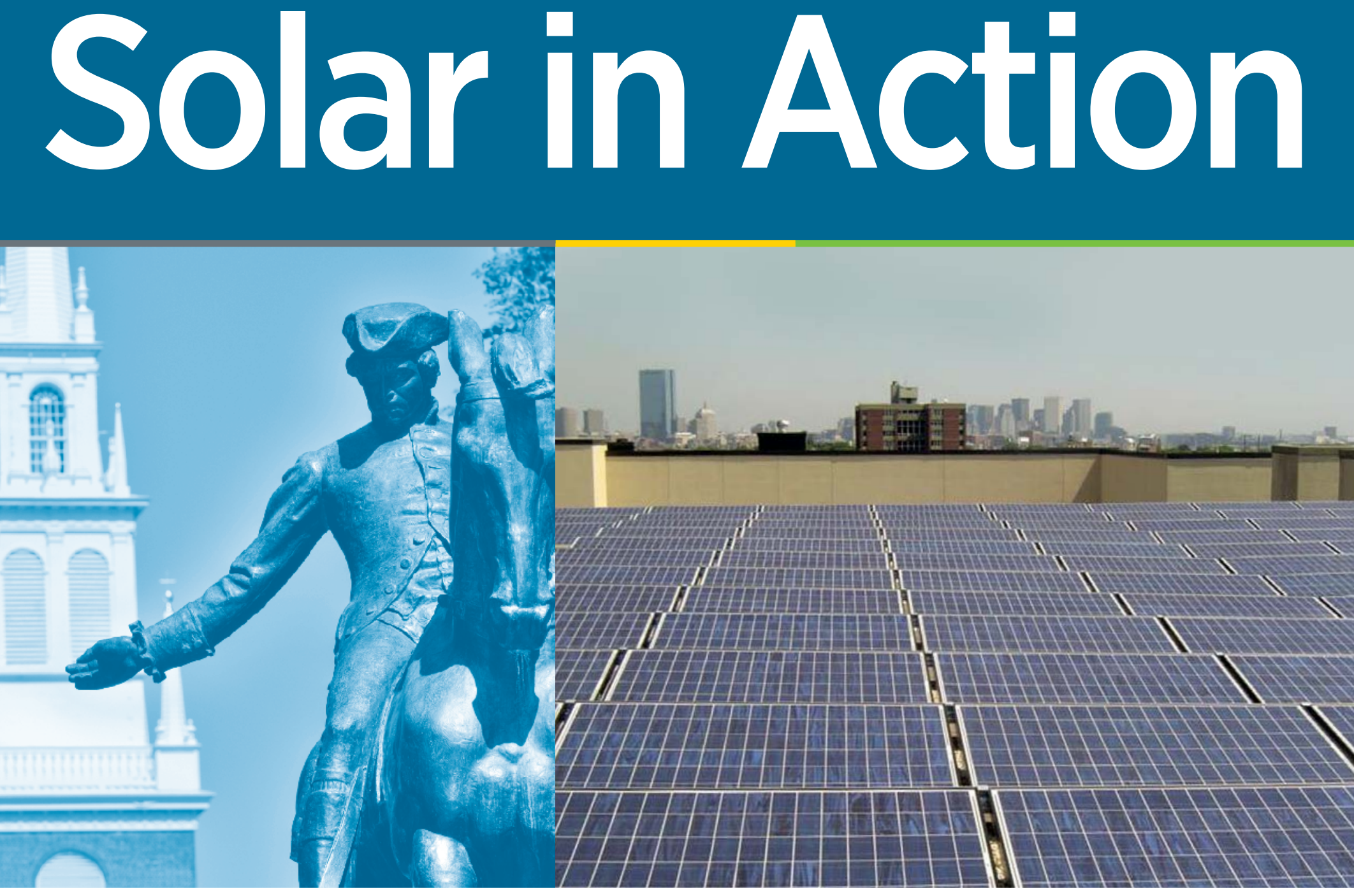

SOLAR AMERICA CITIES

Part of the Solar America Communities program

October 2011

\section{Boston, Massachusetts}

Includes case studies on:

- Incorporating Solar into Emergency Preparedness Planning

- Developing the Boston Solar Map 


\section{Boston's Starting Point}

Boston was designated by the U.S. Department of Energy (DOE) on June 20, 2007, as a Solar America City. Boston has been a leader in climate action since at least 2000, when Mayor Thomas Menino enlisted Boston in the Cities for Climate Protection Campaign run by ICLEl-Local Governments for Sustainability. In the succeeding 10 years, Boston city government has taken many significant steps, among them:

Cover photos from iStock/9413960, Boston's statue of Paul Revere and Old North Church.

\section{About the U.S. Department of Energy's Solar America Communities program:}

The U.S. Department of Energy (DOE) designated 13 Solar America Cities in 2007 and an additional 12 cities in 2008 to develop comprehensive approaches to urban solar energy use that can serve as a model for cities around the nation. DOE recognized that cities, as centers of population and electricity loads, have an important role to play in accelerating solar energy adoption. As a result of widespread success in the 25 Solar America Cities, DOE expanded the program in 2010 by launching a national outreach effort, the Solar America Communities Outreach Partnership. As the Solar America Cities program evolved to include this new outreach effort, the program was renamed Solar America Communities to reflect DOE's commitment to supporting solar initiatives in all types of local jurisdictions, including cities and counties. Visit Solar America Communities online at www.solaramericacommunities.energy.gov.
- In 2002, Boston completed its first green municipal building, the George Robert White Environmental Conservation Center.

- In 2004, the Mayor's Green Building Task Force issued recommendations that led to the adoption of Boston's green building zoning requirements.

- In 2005, Boston's Energy Management Board completed an Integrated Energy Management Plan for 362 municipal buildings.

- In 2007, the Boston Zoning Commission adopted a green buildings provision for Boston's zoning code, which required that large projects meet higher environmental and energy standards.

Also in 2007, Mayor Menino issued an executive order "relative to climate action in Boston," which established the goal of reducing municipal greenhouse gas emissions by $80 \%$ by 2050 . The order set broad guidelines for reaching that goal, including higher efficiency standards for municipal buildings, the purchase of more renewable energy, and a requirement for more efficient vehicles.

The executive order also called for Boston to adopt a climate action plan, to be updated every 3 years, and to form a "community climate action task force." The first climate action plan was published at the end of that year.

\section{Building Partnerships and Setting Goals}

In 2008, with support from the Solar America Cities grant, Boston city government formed Solar Boston, a 2-year initiative to increase solar energy installations in Boston by a factor of 50 .

As the capital city of Massachusetts and the New England region, the City of Boston's objective in establishing and supporting Solar Boston is 
to maximize solar technology's role in the sustainable development, educational, and emergency preparedness policies of Boston, the Commonwealth of Massachusetts, and the region. Solar Boston's objective is the installation of solar technology on all feasible and appropriate locations throughout Boston.

Boston began the Solar America Cities program with an existing installation of 42.5 kilowatts $(\mathrm{kW})$ of photovoltaic (PV) generation. The Mayor's Integrated Energy Management Plan (2005) provided a basis to integrate solar technology into city energy planning and facilities. Implementation of the Mayor's Green Building Task Force recommendations, including first-in-the-nation private development green building requirements (2007), framed the effort to streamline city-level regulations and practices that affect solar adoption by residents and local businesses (e.g., permitting, inspections, local codes). The location within city government of the Solar Boston program and the facilitation of the Solar Boston Partnership built on extensive work by the MTC Renewable Energy Trust and the former DOE Million Solar Roofs program to promote solar technology among residents and local businesses.

The city has established the following quantitative goals:

Greenhouse gas reduction goal: 80\% below 1990 levels by 2050 (Boston Climate Action Initiative)

Solar installation goal: 25 megawatts (MW) cumulative installed solar capacity in the city by 2015

The reinvigorated Solar Boston Partnership builds on the work of Million Solar Roofs and includes many partners within city government and private industry including:

\section{Installed Capacity}

Boston

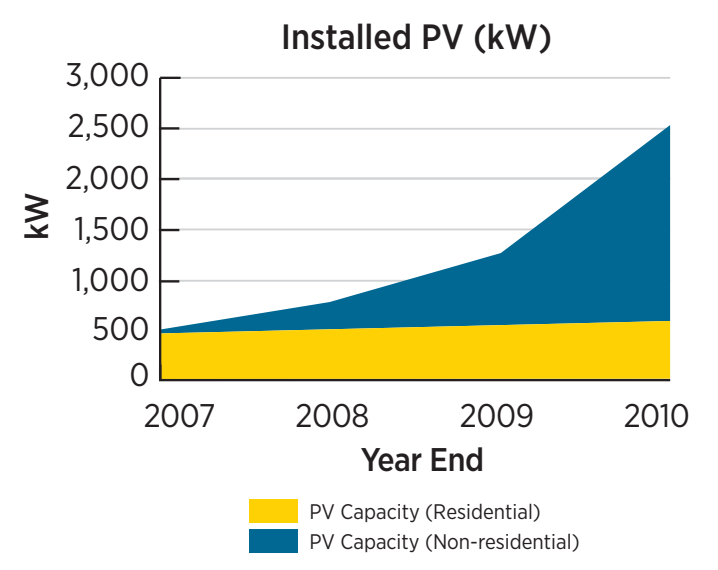

Installed PV capacity increase from December 31, 2007, to December 31, 2010

- City of Boston

- Mayor's Office of Environmental and Energy Services

- Boston Public Schools

- Department of Neighborhood Development

- Boston Housing Authority

- Boston Redevelopment Authority, Planning and Economic Development Agency

- Boston Public Health Commission

- Mayor's Office of Emergency Preparedness

- MTC Renewable Energy Trust

- Distributed Generation Collaborative 
- Commonwealth of Massachusetts, Division of Energy Resources

- NSTAR (electric utility)

- KeySpan (gas utility with solar thermal program)

- International Brotherhood of Electrical Workers Local 103

- Boston Community Capital

- SEBANE (Solar Energy Business Association of New England)

- ICLEI-Local Governments for Sustainability

- Massachusetts Energy Consumers Alliance

- Green Roundtable

- New Ecology, Inc.

\section{Accomplishments and Highlights}

The City of Boston and its Solar America Cities program, Solar Boston, are helping to debunk the myth that solar energy is only feasible in the southern latitudes. Boston has some of the highest energy prices in the country and will likely be one of the first locations where solar power achieves grid parity with conventional energy technologies. Solar Boston is facilitating the rapid development of solar energy projects and infrastructure in the short-term, and is preparing for the rapid market growth that is expected with the imminent arrival of grid parity over the long-term.

Solar Boston developed the strategy for achieving Mayor Menino's goal of installing $25 \mathrm{MW}$ of solar energy throughout Boston by 2015. Through Solar Boston, the city has developed a strategy for the installation of solar technology throughout Boston, including mapping feasible locations, preparing a permitting guide, and planning the citywide bulk purchase, financing, and installation of solar technology.

The city has also worked with local organizations to maximize Boston's participation in state incentive programs and innovative financing initiatives.

The resulting accomplishments include the following:

- Created an online map of current local renewable energy projects with a tool to allow building owners to calculate their rooftop solar potential. The map is currently live at http://gis.cityofboston.gov/solarboston/

- Supported the city's Green Affordable Housing Program (GAHP), in partnership with the Department of Neighborhood Development (DND). Under GAHP, the city is installing more than $150 \mathrm{~kW}$ of PV on 200 units of affordable housing. DND requires that all new city-funded affordable housing be LEED silver certified and built solar-ready

- Defined solar's role in emergency preparedness with the Boston Mayor's Office of Emergency Preparedness

- Worked with local organizations to maximize Boston's participation in state incentive programs and innovative financing mechanisms.

Solar Boston partners include DOE, MTC, local utilities and unions, an anonymous foundation, and a broad range of local, regional, and national clean-energy stakeholders. Solar Boston kicked off its partner program on January 10, 2008, sponsoring a workshop on "Thinking BIG about Boston's Solar Energy Future," to discuss how state, utility, and municipal programs can work together. Presentations were given by Solar Boston, Keyspan/ National Grid, NSTAR, and MTC.

\section{Case Studies: Successes and Challenges}

\section{Incorporating Solar into Emergency Preparedness Planning}

In addition to recognizing that solar energy applications can be used to meet sustainability and greenhouse gas reduction goals, Boston also recognizes that solar power can provide a useful backup to critical applications in the event of a widespread blackout. With assistance from the consulting firm, CH2M HILL, and the National Renewable Energy Laboratory (NREL), Solar Boston completed a crossdepartment emergency preparedness survey that examined solar power applications that could support the city's emergency preparedness infrastructure.

Participants in this process included representatives from the following institutions: 
- Boston Police Department

- Boston Transportation Department

- Boston Fire Department

- Boston Emergency Medical Service

- Boston Public Health Commissions

- Mayor's Office of Emergency Preparedness.

This collaborative brainstorming process was a rare opportunity for these departments to think creatively about the critical nexus of energy and emergency services. Completed in June 2009, this survey examined 13 emergency applications, from large-scale backup power generators for emergency shelters to low-wattage anti-idling systems for police cruisers. The results of the solar emergency preparedness study highlighted several key solar applications that the city could immediately integrate into Boston's existing infrastructure.

In the event of an emergency, Boston's mass evacuation plan calls for residents to exit the city along one of several designated evacuation routes. Many of these main arteries are equipped with emergencyrelated equipment such as evacuation signage and video monitoring equipment as well as critical systems that serve both emergency- and non-emergency-related functions like traffic lights and street lighting. Solar energy systems can provide the power for these important systems, which would otherwise be compromised in the event of a power outage.

\section{Developing the Boston Solar Map}

Solar Boston worked with geographic information system (GIS) professionals from the Boston Redevelopment Authority and the city's information technology department to develop a GIS-based solar map. The map identifies the location of each PV and solar hot water installation in the city. The mapping data is based on installer surveys. Installers were asked to provide photographs of their installations, many of which are featured on the map. The mapping tool was built using open-source principles. The map code has been provided to a number of other municipalities around the country to help with the development of their own solar maps.
In addition to displaying solar installations in Boston, the map has a number of other unique features. These include:

- Layers that show the NSTAR area network, the historic preservation districts, and the relative solar radiation that falls on each building in the city

- A tool that automatically calculates potential PV system size and output, taking into account shading from surrounding buildings. The tool also calculates air emissions reductions based on the Massachusetts-specific multipliers developed as part of the Solar Boston grant

- A tracking meter that shows progress toward the mayor's goal of $25 \mathrm{MW}$ of solar by 2015.

The Solar Boston map has received some notable publicity in the GIS community. The City of Boston staff spoke at a number of conferences detailing the development of the map, which was featured in a GIS trade publication. The city was also contacted by a number of municipalities, including several international cities, inquiring about the solar mapping process.

Solar Boston also used the map to estimate the potential for Boston roofs to accommodate solar installations. Using the map, staff estimated that between 670 and 900 MW of PV could be installed on Boston rooftops.

The city also partnered with NREL to complete a high-density light detection and ranging (LiDAR) scan of the city. This scan provides data that will be used to enhance the Solar Boston map and improve its ability to calculate potential installation sizes and outputs.

The Solar Boston team believes that the depiction of the NSTAR area network is the first public display of such a system in the United States. The area network is an area of the grid that cannot typically integrate PV systems without special engineering considerations. The Solar Boston map provides this critical information to Boston businesses and residents, allowing them to make informed decisions about pursuing PV projects on their buildings. The map also has information about state and federal incentive programs, historic preservation guidelines, and commonly asked questions. 


\section{Top Takeaways}

The Solar Boston map has been a useful marketing and outreach tool for the city. Leveraging existing internal city expertise resulted in a low-cost, high-quality map that is replicable in other communities. Other DOE Solar America Cities invested significant resources to hire an outside firm to produce their solar maps. One lesson the city has learned from the mapping experience has been that a defined process for continually updating the map is needed. The city has hired interns on a bi-annual basis to update the database.

Boston identified a number of barriers to the widespread adoption of solar in the city. Many of these obstacles are common to all cities, including financing, public awareness, and installer training. The Solar Boston program also identified a number of barriers that are less evident, but that also present major hurdles to solar installations. One of the most pressing issues that Solar Boston has tried to overcome is an institutional reluctance to adopt solar technologies. The Solar Boston program successfully introduced solar technologies to a number of municipal agencies including the Boston Public Health Commission, the Boston Water and Sewer Commission, and Boston Public Schools, with plans for working with other municipal agencies in the future.

In addition, the city identified public-sector funding gaps as another barrier to municipal solar technology adoption. Boston, like many cities, is operating in a budgetconstrained environment, and aggressive funding for solar application deployment on municipal buildings is unlikely to occur until the economy improves. The city has identified the green economy and, in particular, the solar industry as critical to the economic future of Boston. Continued publicsector adoption of solar technologies will be necessary to fully develop the industry. In order to support the growth of solar during the economic downturn, the city will need to access new funding sources and deploy applications that provide a better return on investment than traditional PV installations.

\section{Next Steps}

\section{Solar America Cities Special Project}

In 2009, the City of Boston applied for and received a DOE Solar America Cities Special Projects grant. The city's goals for this project are to:

- Prove the effectiveness of solar energy applications in emergency preparedness

- Increase the portion of municipal energy consumption from renewable energy sources

- Establish a cross-cutting collaborative project involving the Boston emergency preparedness community, including transportation and public works professionals and the Boston Police Department

- Provide an effective and reliable energy source for critical evacuation route applications by incorporating solar technologies

- Install, develop, monitor, and optimize the performance of new technologies and applications that will inform future procurement decisions

- Create a successful model for replication by other cities in the Commonwealth and across the nation.

As part of follow-on work to the Solar Boston initiative, the city is piloting a residential solar rebate program funded by the American Recovery and Reinvestment Act to increase market penetration of solar technologies. Boston is also working to develop a neighborhood-level, commercial building solar challenge that will include focused marketing efforts and district-level mayoral installation goals.

\section{Additional Resources}

- City of Boston Solar Boston Website: www.cityofboston.gov/environmentalandenergy/ conservation/solar.asp

- Solar Boston GIS Map: http://gis.cityofboston.gov/solarboston/

- Northeast Sustainable Energy Association: www.nesea.org/

- Boston Area Solar Energy Association: www.basea.org/

- Massachusetts Clean Energy Center: www.masscec.com 


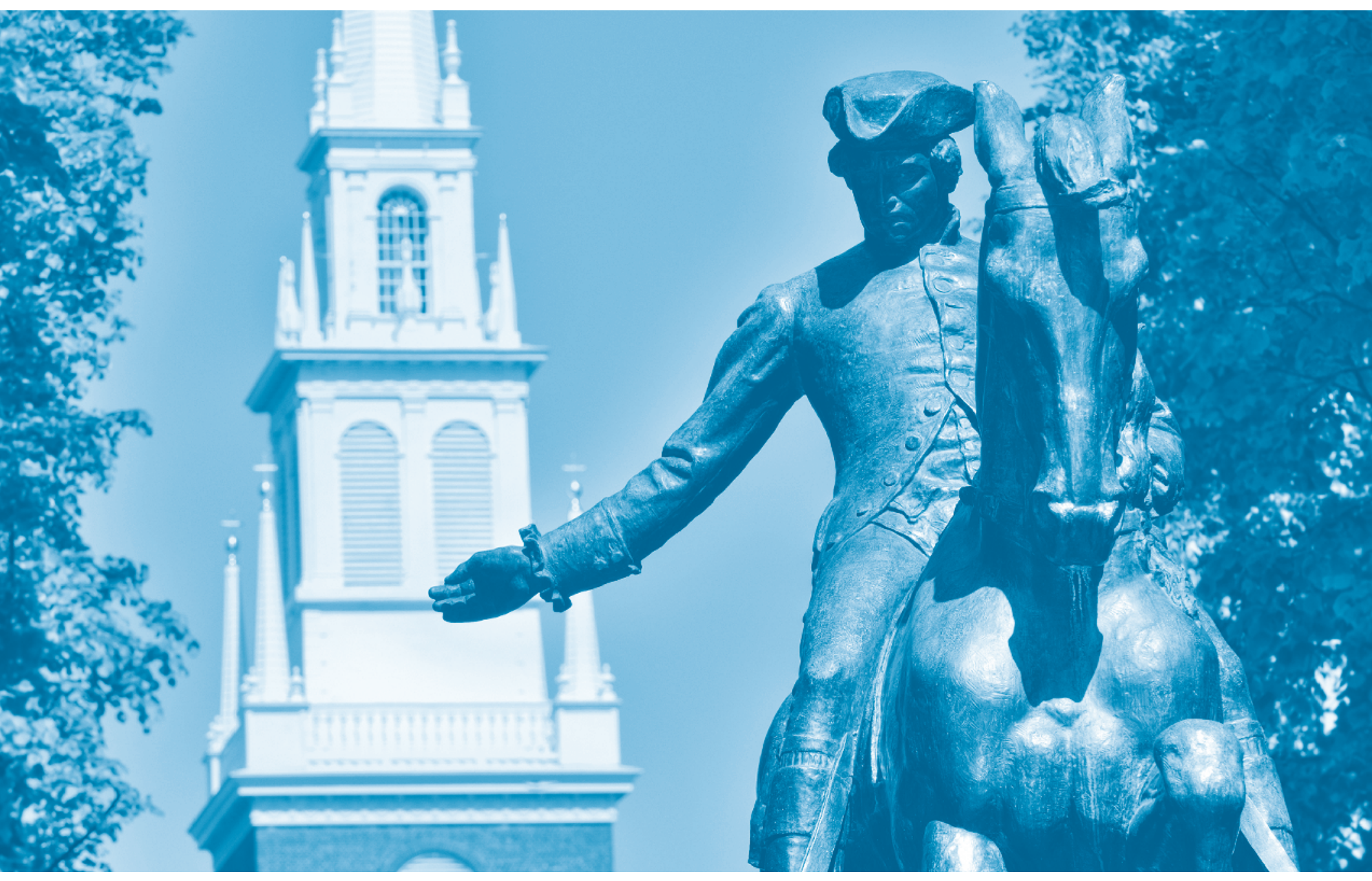

Boston's statue of Paul Revere and Old North Church. Photo from iStock/9413960

For more city information, contact:

Bradford Swing, Director of Energy Policy, Office of the Mayor, Environmental and Energy Services

Email: brad.swing@cityofboston.gov Telephone: 617-635-3425

For more information on going solar in your community, visit Solar Powering Your Community: A Guide for Local Governments at http://solaramericacommunities.energy.gov/resources/guide_for_local_governments/ 
Ann Arbor Austin Berkeley Boston Denver Houston Knoxville Madison Milwaukee Minneapolis-Saint Paul New Orleans New York Orlando Philadelphia Pittsburgh Portland Sacramento Salt Lake City San Antonio San Diego San Francisco San José Santa Rosa Seattle Tucson
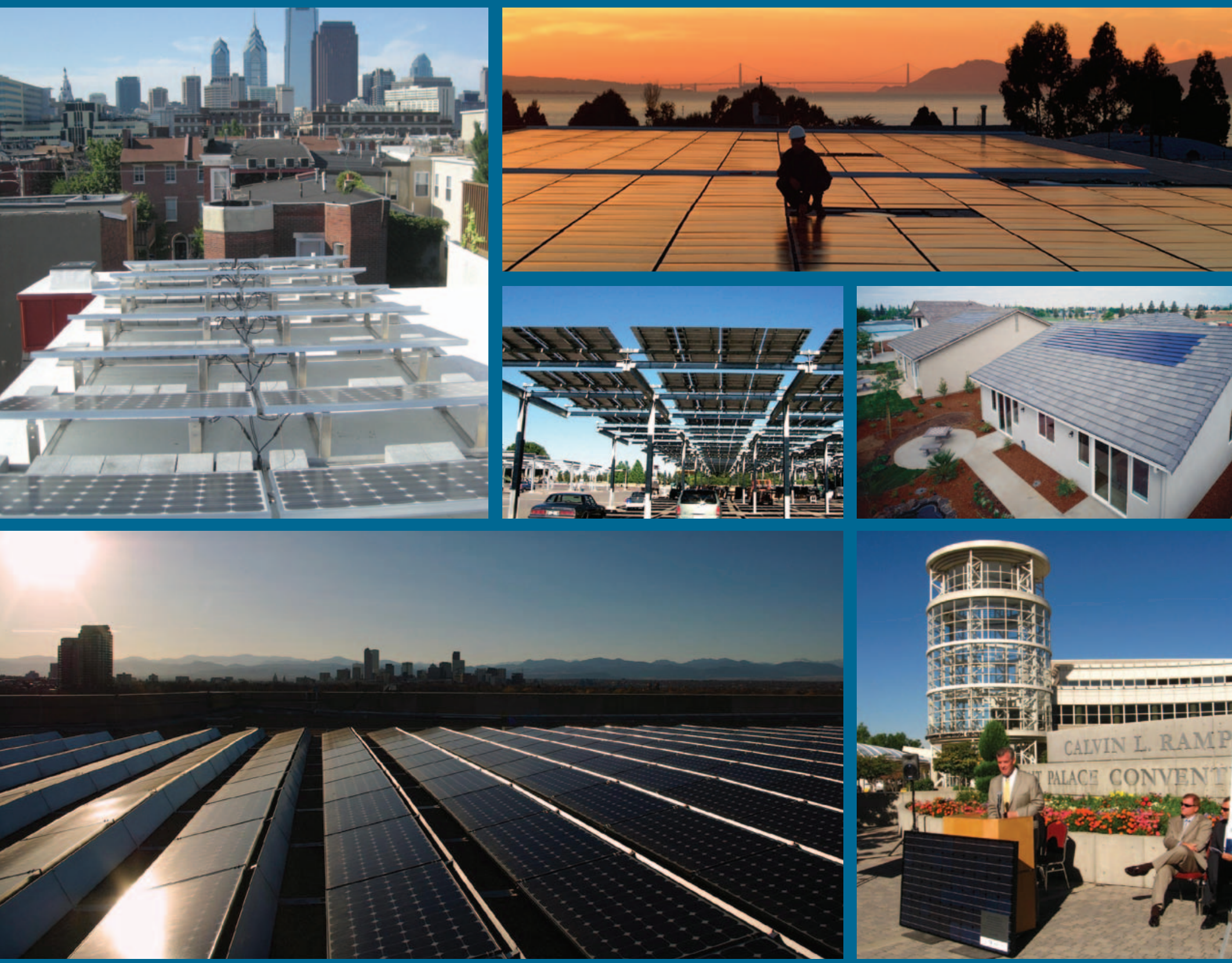

Clockwise from top left: Photovoltaic system in Philadelphia Center City district (photo from Mercury Solar Solutions); rooftop solar electric system at sunset (photo from SunPower, NREL/PIX 15279); Premier Homes development with building-integrated PV roofing, near Sacramento (photo from Premier Homes, NREL/PIX 15610); PV on Calvin L. Rampton Salt Palace Convention Center in Salt Lake City (photo from Utah Clean Energy); PV on the Denver Museum of Nature and Science (photo from Denver Museum of Nature \& Science); and solar parking structure system at the Cal Expo in Sacramento, California (photo from Kyocera Solar, NREL/PIX 09435)

\section{a ENERCY}

Energy Efficiency \& Renewable Energy
EERE Information Center

1-877-EERE-INFO (1-877-337-3463)

www.eere.energy.gov/informationcenter

Printed with a renewable-source ink on paper containing at least $50 \%$ wastepaper, including $10 \%$ post consumer waste.
Prepared by the National Renewable Energy Laboratory (NREL) NREL is a national laboratory of the U.S. Department of Energy Office of Energy Efficiency and Renewable Energy Operated by the Alliance for Sustainable Energy, LLC

DOE/GO-102011-3212 • October 2011 